\title{
Biodenitrification of concentrated red beet juice
}

\author{
Dorota Walkowiak-Tomczak
}

Received: 25 January 2012/Revised: 12 July 2012/ Accepted: 23 July 2012/Published online: 8 August 2012

(C) The Author(s) 2012. This article is published with open access at Springerlink.com

\begin{abstract}
The aim of the study was to determine the possibility to microbiologically remove nitrates from a concentrated red beet juice $(3600 \mathrm{mOsm} / \mathrm{kg}$ ) using halophilic bacteria, Halobacterium mediteranei, Halobacterium denitrificans, and Micrococcus halobius. As a result of microbiologic denitrification, dry matter content in the beet juice concentrate was reduced about $10 \%$ and $\mathrm{pH}$ was found to decrease from 7.0 to 6.2. The content of nitrates in the concentrate decreased from 20 to $37 \%$, but in the diluted concentrate, the reduction rate of nitrates was higher, from 32 to $75 \%$. The highest denitrification rate was recorded for bacteria Micrococcus halobius. As a result of the fermentation process, changes in colour and contents of betalain pigments were observed. The content of betacyanin pigments decreased, while that of betaxanthin pigments increased.
\end{abstract}

Keywords Red beet juice - Denitrification - Nitrate . Halophilic bacteria

\section{Introduction}

Red beets, very popular root vegetables of the temperate climate zone, exhibit valuable nutritional and dietary properties. They contain minerals $(\mathrm{Ca}, \mathrm{K})$, saccharides, dietary fibre and folates [1]. They exhibit antimutagenic [2] and antioxidant properties [3, 4]. They are also used as a source of natural food colour agents (E 162). Their processing

D. Walkowiak-Tomczak ( $\square)$

Institute of Food Technology of Plant Origin,

University of Life Sciences, Wojska Polskiego 28 street,

Poznań, Poland

e-mail: tomczak@up.poznan.pl comprises production of preserves, salads, juices, juice concentrates, dried beets and colouring agents. Red beet pigments are used in the form of concentrated liquid concentrates or in a powdered form [5]. However, this vegetable tends to accumulate nitrates. Apart from species- and cultivar-specific traits, the accumulation of excessive amounts of nitrates is also influenced by agricultural and environmental conditions, such as soil type, fertilisation, date of harvest, precipitation and insolation [6]. Nitrate level in the raw material after harvest changes, depending first on storage conditions and then on processing conditions [7]. Generally, vegetables supply approx. $80 \%$ nitrate uptake in the daily diet [8]. According to literature data, the content of nitrate ions in red beets ranges from several hundred to several thousand $\mathrm{mg} / \mathrm{kg}$ fresh weight $[6,9]$.

For many years, consumption of excessive amounts of nitrates has been considered harmful and it is connected with their potential reduction to nitrites, both in the processed food and in the organism. In view of recent studies, nitrates and nitrites may also exhibit a beneficial effect on human health. Nitrites are ascribed antibacterial activity in relation to pathogenic gastrointestinal bacteria [10]. According to the latest literature data a high nitrate uptake has a beneficial effect on the functioning of the brain in elderly people thanks to improved perfusion [11], it enhances physical fitness of the organism [12] and exercise tolerance in patients suffering from the peripheral arterial disease (PAD) [13]. Thus, the consumption of red beet juice containing nitrates is attributed the capacity to lower blood pressure, prevent platelet aggregation or reduce oxygen demand of muscles [14]. These studies were conducted with the participation of adults. However, it is also known that nitrites cause methemoglobinemia, a disease particularly dangerous for infants, consisting in the blocking of oxygen binding by haemoglobin, resulting in 
anoxia [7, 15]. Cases of methemoglobinemia in infants, as well as children several years of age, were recorded in recent years after consumption of homemade, inappropriately stored soup or vegetable puree, salad or beets [1618]. Moreover, reduced nitrates constitute a nitrosazing factor in the formation of nitrosoamines, exhibiting carcinogenic and mutagenic action [19, 20]. Thus, excessive amounts of nitrates need to be removed from juices, concentrates and colouring agents made from red beets to be used by the general public.

Apart from the application of rational fertilisation and appropriate cultivation measures, methods were developed to reduce nitrates in vegetables and their processed products through physicochemical or biological processes [20, 21]. These methods are also used to remove nitrates from drinking water and effluents [22, 23]. The process of microbiological denitrification occurs also during fermentation of meat products, for example, in the production of fermented sausages [24]. The factor providing specific sensory attributes and microbiological stability of the final products is associated with nitrates added to the meat batter with the starter culture. Bacteria from the starter culture reduce nitrates to nitrites through NO (nitrogen monoxide) to $\mathrm{N}_{2}$. Denitrifying bacteria utilise nitrates as the final acceptors of electrons under anaerobic conditions, the socalled nitrate respiration process. Growth and activity of such a bacterial culture depends on the concentration of nitrates. Their high concentration inhibits nitrite reduction, and the presence of oxygen inhibits reduction of both nitrates and nitrites [24]. Generally denitrifying bacteria maintain the cycle of nitrogen in nature and thus life on Earth. Denitrification prevents nitrate leaching from soil and their accumulation in oceans, which otherwise would lead to the inhibition of biomass production. Nitrogen in organic and inorganic compounds thanks to denitrification is released and incorporated in the cycle [25]. Thanks to microbiological denitrification, it is possible to completely eliminate nitrates from red beet juice [21, 26]. However, during microbiological processes, changes occur in sensory attributes of juice, particularly colour, which intensity depends on the applied bacterial strains [4]. Red beet juice is subjected to lactic fermentation also in order to obtain a probiotic product, while on the other hand, strains applied in lactic acid fermentation, for example, Lactobacillus plantarum, may exhibit activity to reduce nitrates and/or nitrites [24, 27]. Such a method provides a product with probiotic properties, at the same time safe in terms of its content of nitrates and nitrites. Using different bacterial strains in the denitrification process, to maintain microbiological safety of consumers, it is necessary to remove from the product bacterial cells, for example, through microfiltration of juice after fermentation or the use of a membrane bioreactor, in which microorganisms are immobilized inside the membrane carrier [20]. Generally, the use of microorganisms in food production is always connected with the necessity to select microorganisms that do not produce toxins or allergens, posing a health hazard for humans and animals [24, 26]. In accordance with the recommendations by the FAO/WHO Expert Committee on Food Additives, the amount of nitrates in colouring preparations obtained from red beets may not exceed the level admissible for foodstuffs for children and infants [28]. This shows the necessity to control the level of nitrates in beets to be used not only in direct consumption, but also in the production of food colouring agents. Under commercial scale production conditions, juices, including red beet juice, are stored in a concentrated form, among other things to reduce their volume and enhance microbiological stability of the product. Running biological reduction of nitrates in an undiluted concentrate, using commonly applied denitrifying bacterial strains, is not sufficiently effective [26]. The application of bacteria capable of growing in a medium with high salt concentration and high osmotic pressure, and at the same time capable of reducing nitrates and nitrites, could facilitate denitrification of condensed red beet juice, that is, of lower volume. Thus, it was decided in this study to use strains of halophilic bacteria purchased from the ATCC collection, described as capable of growth under such conditions and exhibiting denitrifying activity [29]. In accordance with the Polish legal regulations, based on the Regulation of the Minister of Health, used strains do not constitute a health hazard in any group of biological hazard [30].

The aim of the study was to determine the possibility to microbiologically remove nitrates from a concentrated red beet juice using halophilic bacteria.

\section{Materials and methods}

\section{Red beet juice concentrate}

Red beet multivarietal concentrate came from a processing plant of Hortex-Holding S.A. in Warsaw, Poland. The initial $\mathrm{pH}$ of the concentrate was 4.5 , the refractometric extract content was approx. $50 \%$, dry matter content was approx. $60 \%$, and osmotic pressure was approx. $3600 \mathrm{mOsm} / \mathrm{kg}$. Nitrate content in the concentrate was determined to be approx. $7 \mathrm{~g} \mathrm{NO}_{3}{ }^{-} / \mathrm{L}$, while nitrites were not detected. Acidity of the concentrate and diluted solutions was adjusted to $\mathrm{pH} 7.0$ using $20 \% \mathrm{NaOH}$ solution. Processes of microbiological denitrification were run using the concentrate and its aqueous solutions diluted at $1: 1$ and 1:2 (concentrate: water). In such prepared solutions, osmotic pressure was approx. 1800 and $1200 \mathrm{mOsm} / \mathrm{kg}$, respectively. 
The concentrate and its aqueous solutions were sterilised by flow pasteurisation $\left(97^{\circ} \mathrm{C}, 105 \mathrm{~s}\right)$, after which they were cooled and poured to sterile 500-ml Erlenmeyer flasks.

\section{Microorganisms}

Analyses were conducted using strains of Halobacterium mediteranei (ATCC 33500, medium 1176-described below), Halobacterium denitrificans (ATCC 35960, medium 1434) and Micrococcus halobius (ATCC 21727, medium 769). Bacteria were proliferated at $30{ }^{\circ} \mathrm{C}$ on media recommended by ATCC.

The strain of $H$. mediteranei was cultured on a medium (ATCC 1176) containing (g/L): $\mathrm{NaCl} 156, \mathrm{MgCl}_{2} \cdot 6 \mathrm{H}_{2} \mathrm{O} 13$, $\mathrm{MgSO}_{4} \cdot 7 \mathrm{H}_{2} \mathrm{O} 20, \mathrm{KCl} 4, \mathrm{CaCl}_{2} \cdot 6 \mathrm{H}_{2} \mathrm{O} 1, \mathrm{NaHCO}_{3} 0.2$, $\mathrm{NaBr}$ 0.5, yeast extract (Difco) 5, glucose 1, pH 7.0.

The starin of $H$. denitrificans was cultured on a medium (ATCC 1434) containing (g/L): $\mathrm{NaCl} 176, \mathrm{MgCl}_{2} \cdot 2 \mathrm{H}_{2} \mathrm{O}$ 20, $\mathrm{KCl} 2, \mathrm{KNO}_{3} 5, \mathrm{CaCl} 2 \cdot 2 \mathrm{H} 2 \mathrm{O}$ 0.1, HEPES buffer 11.9, yeast extract (Difco) 5, pH 6.7.

The strain of $M$. halobius was cultured on a medium (ATCC 769) containing (g/L): $\mathrm{NaCl} 116, \mathrm{FeCl}_{2} 23$, $\mathrm{MgSO}_{4} \cdot 7 \mathrm{H}_{2} \mathrm{O} 20, \mathrm{KCl} 2$, citric acid 3, yeast extract (Difco) 10 , vitamin-free hydrolysate $7.5, \mathrm{pH} 6.2$.

Strains for direct use were cultured and stored on agar slants with the above-specified composition with an addition of $2 \%(\mathrm{w} / \mathrm{v})$ agar at a temperature of $4{ }^{\circ} \mathrm{C}$, while the museum collection was stored in a glycerol solution $(50 \%$, v/v) at $-70{ }^{\circ} \mathrm{C}$.

\section{Denitrification methods}

Denitrification methods were run in Erlenmeyer flasks, to which pasteurised juice concentrate or its aqueous solution was introduced aseptically at $400 \mathrm{~mL}$ and $10 \%$ (v/v) inoculum from a 48 -h growth of culture with cell density of approx. $10^{8} \mathrm{cfu} / \mathrm{mL}$. The process was run in tightly sealed Erlenmeyer flasks, with no access of air, under facultative anaerobic conditions at $30{ }^{\circ} \mathrm{C}$ for $48 \mathrm{~h}$. After fermentation, juice was centrifuged in order to remove the bacterial culture. Each experiment was performed in three series, of three replications each. Results are presented as means.

\section{Analytical methods}

All analyses concerned changes in the chemical composition of red beet concentrate were performed on a supernatant obtained as a result of centrifugation of the concentrate, both before and after denitrification (Beckman 12, $12000 \mathrm{rpm}, 15 \mathrm{~min})$. Dry matter content in the red beet juice concentrate was determined by gravimetry, drying the sample at $70{ }^{\circ} \mathrm{C}$ for $4 \mathrm{~h}$, and next at $105^{\circ} \mathrm{C}$ to constant weight.

Contents of nitrates and nitrites were determined by high-performance liquid chromatography (HPLC) using a Spectro System UV 3000 chromatograph with a UV detector (Thermo Separation Products), a precolumn (silica gel Alltech) and a Phase Separation Spheris ORB S5SAX column. Potassium phosphate $\mathrm{KH}_{2} \mathrm{POP}_{4} 0.05 \mathrm{M}$, pH 3.2 was applied as an eluent at a flow rate of $1 \mathrm{~mL} / \mathrm{min}$, the temperature of the column at $20{ }^{\circ} \mathrm{C}$ and pressure of 115 bar. Prior to HPLC analyses, concentrate samples were diluted and microfiltrated $(0.22 \mu \mathrm{m}$, Millipore filter).

Contents of betalain pigments, betacyanins and betaxanthins were determined by differential spectrophotometry [31]. Prior to measurements, a concentrate sample was diluted using $0.1 \mathrm{M}$ phosphate buffer at $\mathrm{pH} 6.5$, so that the extinction value fell within the range of 0.3-0.8. Content of red pigments, expressed as betanin content, was determined on the basis of extinction value measured at $538 \mathrm{~nm}$, while that of yellow pigments, expressed as the content of vulgaxanthin I, at a wavelength of $476 \mathrm{~nm}$. When calculating contents of red and yellow pigments, a correction was included, resulting from absorbance of light by impurities present in the sample, on the basis of measurements of extinction at $600 \mathrm{~nm}$. Phosphate buffer at $\mathrm{pH} 6.5$ was used as a blank test.

\section{Results and discussion}

Red beet juice is produced and stored in the form of concentrate (60-70\% extract), which facilitates storage and reduces its costs. In view of the necessity to remove nitrates from the raw material to be used in the production of pigments, juices and other foodstuffs, particularly those for children and infants, it would be beneficial to run denitrification directly in the concentrate. Due to the high osmotic pressure in a concentrated juice, halophilic bacteria were used as denitrifying microorganisms.

Level of $\mathrm{pH}$ and dry matter content

Prior to the denitrification process, the $\mathrm{pH}$ level of the concentrate and its solutions was adjusted to approx. 7.0. After a 48-h culture, $\mathrm{pH}$ was found to decrease in the medium in all analysed cases (Table 1 ). The $\mathrm{pH}$ value after culture was 6.8 in the concentrate, 6.6-6.7 in $1 \times$ diluted concentrate and 6.2-6.4 in $2 \times$ diluted concentrate. On the basis of a one-way analysis of variance, no significant effect $(p \leq 0.05)$ was found for the bacterial species on changes in $\mathrm{pH}$ values in the medium after culture. In turn, a statistically significant effect $(p \leq 0.05)$ on this variable was observed for the concentrate dilution rate. An increase 
Table 1 The effect of microbiological denitrification of beet juice concentrate on $\mathrm{pH}$ and dry matter contents in the concentrate, depending on concentrate dilution rate a Dilution rate: 0 , undiluted (3600 mOsm $/ \mathrm{kg}) ; 1,1 \times$ dilution $(1800 \mathrm{mOsm} / \mathrm{kg}) ; 2$, $2 \times$ dilution $(1200 \mathrm{mOsm} / \mathrm{kg})$

\begin{tabular}{lllll}
\hline Bacterial strain & $\begin{array}{l}\text { Concentrate } \\
\text { dilution }^{\mathrm{a}}\end{array}$ & $\mathrm{pH}$ & $\begin{array}{l}\text { Dry matter content } \\
{[\mathrm{g} / \mathrm{L}]}\end{array}$ & $\begin{array}{l}\text { Nitrate content } \\
{[\mathrm{g} / \mathrm{L}]}\end{array}$ \\
\hline Initial concentrate & 0 & $7.0 \pm 0.04$ & $598 \pm 23.7$ & $7.28 \pm 0.29$ \\
& 1 & $7.0 \pm 0.06$ & $310 \pm 7.2$ & $3.64 \pm 0.14$ \\
Halobacterium mediteranei & 2 & $7.0 \pm 0.06$ & $205 \pm 10.0$ & $2.42 \pm 0.09$ \\
& 1 & $6.8 \pm 0.09$ & $533 \pm 56.1$ & $5.78 \pm 0.71$ \\
Halobacterium denitrificans & 0 & $6.6 \pm 0.27$ & $288 \pm 19.0$ & $2.46 \pm 0.27$ \\
& 1 & $6.3 \pm 0.17$ & $191 \pm 8.2$ & $0.99 \pm 0.26$ \\
Micrococcus halobius & 2 & $6.8 \pm 0.10$ & $539 \pm 29.6$ & $5.24 \pm 0.19$ \\
& 0 & $6.7 \pm 0.10$ & $290 \pm 11.1$ & $2.26 \pm 0.43$ \\
& 1 & $6.2 \pm 0.12$ & $194 \pm 6.3$ & $1.05 \pm 0.13$ \\
& 2 & $6.8 \pm 0.10$ & $538 \pm 42.8$ & $4.56 \pm 0.72$ \\
& $6.6 \pm 0.14$ & $280 \pm 13.8$ & $1.48 \pm 0.26$ \\
& & $6.4 \pm 0.05$ & $189 \pm 13.0$ & $0.61 \pm 0.12$ \\
\hline
\end{tabular}

in medium acidity during denitrification run by halophilic bacteria was also described by other authors, who observed that carbohydrate uptake by these microorganisms was accompanied by the production of acids [32].

As a result of microbiologic denitrification, dry matter content in the beet juice concentrate was reduced, since heterotrophic bacteria use its components as a source of carbon. Dry matter content in the initial concentrate was 598, 310 and $205 \mathrm{~g} / \mathrm{L}$, respectively, in the undiluted concentrate and in its $1 \times$ and $2 \times$ dilutions (Table 1 ). After denitrification, culture dry matter content was recorded to decrease by $5.4-7.7 \%$ in a $2 \times$ diluted concentrate, up to 9.9-10.8\% in the concentrate (Fig. 1). Similarly as in case of $\mathrm{pH}$ changes, a one-way ANOVA showed a lack of a significant effect $(p \leq 0.05)$ of the bacterial strain on the losses of dry matter in the culture medium, as opposed to a significant effect of the concentration of the concentrate on this variable. As a result of denitrification run in a condensed concentrate, dry matter losses amounted to approx. $10 \%$, irrespective of the applied bacterial species. In turn, in cultures where diluted concentrate was applied as the medium, the greatest dry matter losses were found in case of Micrococcus halobius, while they were smallest in case of Halobacterium denitrificans. In earlier studies with the use of Paracoccus denitrificans, dry mater losses in diluted juice after a 24-h culture under identical conditions $\left(30^{\circ} \mathrm{C}\right.$, $\mathrm{pH} 7.0$ ) amounted to $14 \%$; however, they were accompanied by a total reduction of nitrates [26].

\section{Reduction of nitrates}

Initial concentration of nitrates in the concentrate was $7.2 \mathrm{~g} / \mathrm{L}$, which exceeded the tolerance limit of most microorganisms. Halophilic bacteria for growth require a high salt concentration in the medium, on average 2-4 M $\mathrm{NaCl}$, that is, approx. 100-200 g/L. However, the other

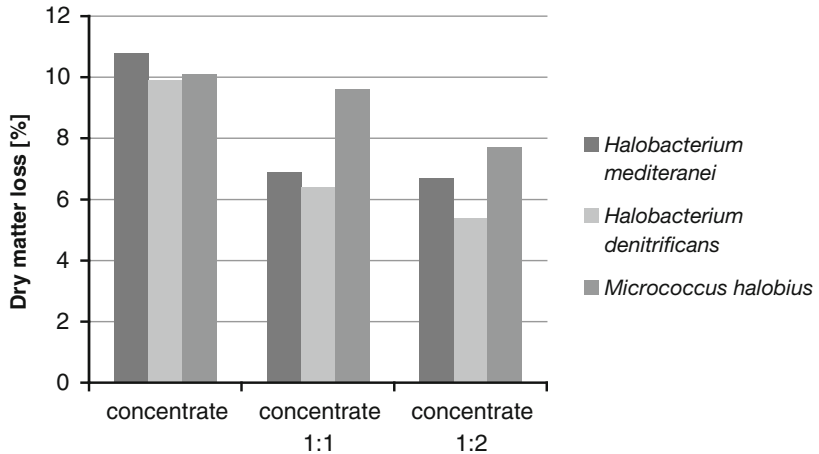

Fig. 1 The effect of microbiological denitrification on dry matter content in red beet juice concentrate

microorganisms usually grow on media containing 3-5 g $\mathrm{NaCl} / \mathrm{L}$, which is to provide adequate osmotic pressure. Bacteria from the genus Halobacterium are extreme halophiles, as they tolerate salt concentrations over $4 \mathrm{M} \mathrm{NaCl}$ (over $200 \mathrm{~g} / \mathrm{L}$ ) [32]. Bacteria Micrococcus halobius are moderate halophiles, as they develop best in media containing up to $3 \mathrm{M} \mathrm{NaCl}(174 \mathrm{~g} / \mathrm{L})$, but they do not grow at concentrated glucose solutions with no sodium chloride added [33]. Such bacteria overgrow media with high nitrate concentrations, over $5 \mathrm{~g} / \mathrm{L}$.

The beet concentrate medium used in this study contained $7.2 \mathrm{~g}$ nitrates/ $\mathrm{L}$ in the initial concentrate, and 3.6 and $2.4 \mathrm{~g} / \mathrm{L}$ in $1 \times$ and $2 \times$ diluted concentrates, respectively (Table 1). As a result of 48-h culture of halophilic bacteria, the content of nitrates in the concentrate decreased by $20 \%$ in case of Halobacterium mediteranei and by as much as $37 \%$ in case of Micrococcus halobius (Fig. 2). In the diluted concentrate, the reduction rate of nitrates was higher. In a $1 \times$ diluted concentrate, nitrate losses amounted to $32-59 \%$, while in a $2 \times$ diluted concentrate, it was from 56 to $75 \%$. In several cases, trace 
amounts of nitrites were found in the post-culture medium. In each culture variant, the highest denitrification rate was recorded for bacteria Micrococcus halobius, although a one-way ANOVA did not show a statistically significant effect $(p \leq 0.05)$ of the bacterial species on the content of nitrates in the post-culture medium. In contrast, a significant effect was found in case of the type of medium (concentrate dilution rate) and the applied bacterial strain in a multivariate analysis of variance for this variable. When using a strain of Paracoccus denitrificans in earlier studies, at a similar nitrate content in the beet juice concentrate, after a 72-h culture, the recorded nitrate reduction rate amounted to approx. $23 \%$ in a $2 \times$ diluted concentrate [21]. In these studies, using halophilic bacteria at an identical concentrate dilution, although at a shorter time $(48 \mathrm{~h})$, the nitrate reduction rate was $32-59 \%$, depending on the strain. However, total nitrate reduction was not obtained in any variant, whereas it was observed during red beet juice denitrification at a natural osmotic pressure.

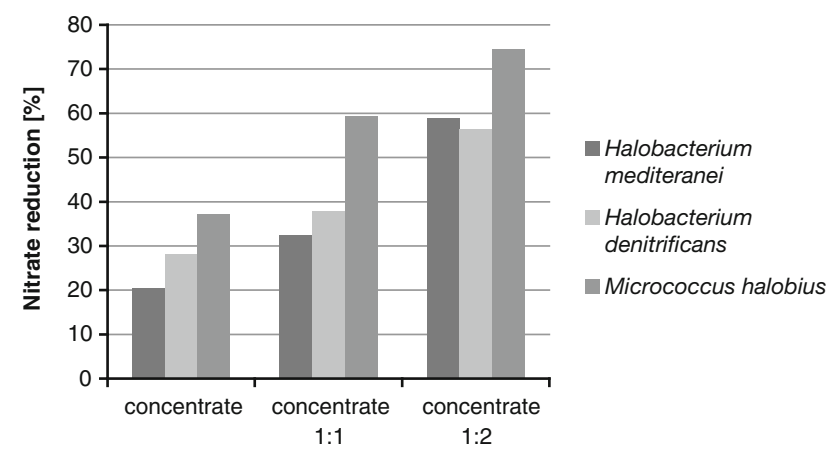

Fig. 2 The effect of microbiological denitrification on the rate of nitrate reduction in red beet juice concentrate
Betalain pigments

As a result of the fermentation process, changes in colour and contents of betalain pigments were observed in red beet juice concentrate. These changes were identical in character in all the cases. The content of betacyanin pigments decreased, while that of betaxanthin pigments increased. The initial content of red pigments in the concentrate, amounting to $290 \mathrm{mg} / 100 \mathrm{~g}$, dropped to approx. $200 \mathrm{mg} / 100 \mathrm{~g}$, irrespective of the applied bacterial strain (Table 2). In $1 \times$ and $2 \times$ diluted concentrates, the level of betacyanins decreased from $145 \mathrm{mg} / 100 \mathrm{~g}$ to $88 \mathrm{mg} / 100 \mathrm{~g}$ and from $97 \mathrm{mg} / 100 \mathrm{~g}$ to approx. $40-45 \mathrm{mg} / 100 \mathrm{~g}$, respectively. A slightly lower content of betacyanins was recorded in case of Halobacterium denitrificans. In turn, the content of betaxanthins after fermentation was higher than in the initial medium, on average by $10-20 \mathrm{mg} / 100 \mathrm{~g}$, which constituted an increase by $5-30 \%$. The recorded increase in the contents of yellow pigments is connected with the degradation of red pigments to brown products, which in the applied spectrophotometric method are assayed together with yellow pigments. The above-mentioned changes in the contents of betalain pigments resulted in a reduction of the ratio of contents of red to yellow pigments (the degradation index) from 1.9 to 1.3 in the concentrate, $0.8-1.1$ in $1 \times$ diluted concentrate and 0.8 in $2 \times$ diluted concentrate, respectively (Table 2 ). Both the one-way and multivariate analyses of variance showed no statistically significant effect $(p \leq 0.05)$ of the type of the applied bacterial strain on the content of betalain pigments or pigment degradation index, while the effect of the type of the beet concentrate was significant.

The decrease in the value of the ratio of betacyanin pigments to that of betaxanthins was reflected in a change in the colour tone of the concentrate or its solutions from
Table 2 The effect of microbiological denitrification of beet juice concentrate on contents of betalain pigments, depending on concentrate dilution rate

\begin{tabular}{clccl}
\hline Bacterial strain & $\begin{array}{l}\text { Concentrate } \\
\text { dilution rate }\end{array}$ & $\begin{array}{l}\text { Contents of red } \\
\text { pigments }[\mathrm{mg} / 100 \mathrm{~g}]\end{array}$ & $\begin{array}{l}\text { Contents of yellow } \\
\text { pigments }[\mathrm{mg} / 100 \mathrm{~g}]\end{array}$ & $\begin{array}{l}\text { Ratio of red to yellow } \\
\text { pigment contents }\end{array}$ \\
\hline Initial & 0 & $290.3 \pm 38.5$ & $147.8 \pm 16.1$ & $1.96 \pm 0.06$ \\
concentrate & 1 & $145.1 \pm 19.2$ & $73.9 \pm 8.0$ & $1.96 \pm 0.06$ \\
& 2 & $96.7 \pm 12.8$ & $49.2 \pm 5.3$ & $1.96 \pm 0.05$ \\
Halobacterium & 0 & $196.5 \pm 12.6$ & $154.5 \pm 6.7$ & $1.28 \pm 0.12$ \\
mediteranei & 1 & $87.9 \pm 14.6$ & $96.5 \pm 11.8$ & $0.92 \pm 0.18$ \\
& 2 & $40.6 \pm 10.9$ & $62.2 \pm 18.6$ & $0.83 \pm 0.23$ \\
Halobacterium & 0 & $200.5 \pm 25.9$ & $153.8 \pm 17.0$ & $1.31 \pm 0.13$ \\
denitrificans & 1 & $72.5 \pm 15.0$ & $91.6 \pm 19.0$ & $0.79 \pm 0.08$ \\
& 2 & $37.6 \pm 6.8$ & $55.6 \pm 5.7$ & $0.78 \pm 0.33$ \\
Micrococcus & 0 & $206.5 \pm 33.1$ & $174.0 \pm 30.1$ & $1.20 \pm 0.18$ \\
halobius & 1 & $88.4 \pm 14.8$ & $79.5 \pm 3.7$ & $1.12 \pm 0.22$ \\
& 2 & $45.6 \pm 8.7$ & $59.4 \pm 14.3$ & $0.82 \pm 0.34$ \\
\hline
\end{tabular}


red-purple to brown-red. The change in the colour tone was more marked in case of diluted concentrates, as in the condensed concentrate, these changes were masked by a high pigment concentration and colour intensity. Presented changes in the betalain pigment contents are connected with acidity of the medium, in which $\mathrm{pH}$ was adjusted to approx. 7.0 as optimal for the applied halophilic bacteria, while $\mathrm{pH}$ of approx. 5.0-5.5 is the value providing the greatest stability of these pigments. Thus, a high stability of betalain pigments is obtained in red beet juices subjected to lactic fermentation when producing probiotic drinks [4]. However, these bacteria exhibit no capacity to reduce nitrates and nitrites.

\section{Conclusions}

Microbiological denitrification of concentrated red beet juice using halophilic bacteria made it possible to remove up to $75 \%$ nitrates within a period of $48 \mathrm{~h}$ in $2 \times$ diluted concentrate $(1200 \mathrm{mOm} / \mathrm{kg})$, but it was only to $37 \%$ in the initial concentrate $(3600 \mathrm{mOm} / \mathrm{kg})$. Based on the analysis of variance, it may be stated that the nitrate reduction rate depended mainly on the concentration of the beet juice concentrate, and not on the applied bacterial strain, although the best denitrification results were recorded in case of bacteria Micrococcus halobius. As a result of denitrification, cultures dry matter content in the concentrate decreased by $5-10 \%$. Running cultures in concentrates at $\mathrm{pH}$ of approx. 7.0 and a temperature of $30^{\circ} \mathrm{C}$, optimal for the applied bacteria, caused changes in the contents of betalain pigments and the quantitative ratio of red to yellow pigments, which resulted in a change in the colour tone towards brown-red. It may be assumed that an extension of microbiological denitrification time in the used beet juice concentrates should increase the reduction rate of nitrates; however, due to the simultaneously progressing changes in the concentration of betalain pigments and colour tone, the time of culture needs to be reduced.

Open Access This article is distributed under the terms of the Creative Commons Attribution License which permits any use, distribution, and reproduction in any medium, provided the original author(s) and the source are credited.

\section{References}

1. Jägerstad M, Pirogen V, Walker C, Ros G, Carnovale E, Holasova M, Nau H (2005) Trends Food Sci Technol 16:298-306

2. Edenharder R, Sager JW, Glatt H, Muckel E, Platt KL (2002) Mutat Res 521:57-72
3. Kanner J, Hardel S, Granit R (2001) J Agric Food Chem 49:5178-5185

4. Czyżowska A, Klewicka E, Libudzisz Z (2006) Eur Food Res Technol 223:110-116

5. Nemzer B, Pietrzkowski Z, Spórna A, Stalica P, Thresher W, Michałowski T, Wybraniec S (2011) Food Chem 127:42-53

6. Ximenes MIN, Rath S, Reyes FGR (2000) Talanta 51:49-56

7. Chan TYK (2011) Toxicol Lett 200:107-108

8. Santamaria P (1997) Ind Aliment 36(364):1329-1334

9. Murawa D, Banaszkiewicz T, Majewska E, Błaszczuk B, Sulima J (2008) Bromat Chem Toksykol XLI 1:67-71

10. McKnight GM, Duncan CW, Leifert C, Golden MH (1999) Br J Nutr 81(5):349-358

11. Presley TD, Morgan AR, Bechtold E, Clodfelter W, Dove RW, Jennings JM, Kraft RA, King SB, Laurienti PJ, Rejeski WJ, Burdette JH, Kim-Shapiro DB, Miller GD (2011) Nitric Oxide 24:34-42

12. Bailey SJ, Winyard P, Vanhatalo A, Blackwell JR, DiMenna FJ, Wilkerson DP, Tarr J, Benjamin N, Jones AM (2009) J Appl Physiol 107:1144-1155

13. Kenjale AA, Ham KL, Stabler T, Robbins JL, Johnson JL, VanBruggen M, Privette G, Yim E, Kraus WE, Allen JD (2011) J Appl Physiol 110:1582-1591

14. Kapil V, Milsom AB, Okorie M, Maleki-Toyserkani S, Akram F, Rehman F, Arghandawi S, Pearl V, Benjamin N, Loukogeorgakis S, McAllister R, Hobbs AJ, Webb AJ, Ahluwalia A (2010) Hypertension 56:274-281

15. Greer FR, Shannon M (2005) Pediatrics 116:784-786

16. Sanchez-Echaniz J, Benito-Fernandez J, Mintegui-Raso S (2001) Pediatrics 107:1024-1028

17. Lu XM, Chen L, Zhang QX (2005) Chin Pract J Rural Doct 12:60

18. Zhang L, Zhou T, Fu SM, Liu YL (2009) J Jinggangshan Univ (Nat Sci Ed) 30:92-94

19. Tsezon A, Kitsion-Tzeli S, Galla A, Gourgiotis D, Papageorgion J, Mitron S, Molybdas PA, Sinaniotis C (1996) Arch Environ Health 51(6):458-462

20. Kolb E, Haug M, Janzowski C, Vetter A, Eisenbrand G (1997) Food Chem Toxicol 35:219-224

21. Walkowiak-Tomczak D (2002) Eur Food Res Technol 215: 401-406

22. Wang Z (1998) Water Sci Tech 37(9):97-104

23. Aslan S, Türkmen A (2004) Environ Int 30:449-455

24. Hammes WP (2012) Food Microbiol 29:151-156

25. Simek M (1998) Rostlinna Vyroba 44(9):385-394

26. Grajek W, Walkowiak-Tomczak D (1997) J Agric Food Chem 45:1963-1966

27. Yoon KY, Woodams EE, Hang YD (2005) LWT 38:73-75

28. FAO/WHO Geneva (1995/2002) Evaluations of the Joint FAO/ WHO Expert Committee on Food Additives (JECFA)

29. American Type Culture Collection (1989) In: Cote R, Pienta P, Gherna R (eds) ATCC Catalogue of bacteria and bacteriophages. Rockville, Maryland

30. Ordinance of the Minister of Health of 22 April 2005 on harmful biological factors posing a health hazard in the workplace and health protection of employees exposed to these factors at work. Dziennik Ustaw .05.81.716

31. Nilsson T (1970) Lantbrukshogskolans Annaler 36:179-197

32. Tomlinson GA, Jahnke LL, Hochstein LI (1986) Int J Syst Bacteriol 36(1):66-70

33. Onishi H, Kamekura M (1972) Int J Syst Bacteriol 22(4):233-236 